American Journal of Environmental Sciences 6 (6): 560-569, 2010

ISSN 1553-345X

(C) 2010 Science Publications

\title{
Variation of Surface Ozone Recorded at the Eastern Coastal Region of the Malaysian Peninsula
}

\author{
${ }^{1}$ Aida Shafawati Ismail, ${ }^{2}$ Mohd Talib Latif \\ ${ }^{1}$ Siti Zawiyah Azmi, ${ }^{2}$ Liew Juneng and ${ }^{1}$ Abdul Aziz Jemain \\ ${ }^{1}$ School of Mathematical Sciences, \\ ${ }^{2}$ School of Environmental and Natural Resource Sciences, \\ Faculty of Science and Technology, University Kebangsaan Malaysia, \\ 43600 Bangi, Selangor Malaysia
}

\begin{abstract}
Problem statement: Variations of ozone $\left(\mathrm{O}_{3}\right)$ concentrations in the Eastern Coastal Region of the Malaysia peninsula were investigated using data obtained from the Malaysian Department of the Environment. The aim of this study was to determine the monthly and seasonal variations of ozone concentrations at all monitoring sites. This study deals with the air quality data recorded at four air quality monitoring stations in the East Coast of the Malaysian peninsula over a ten year period (19972006). Approach: We focused on the usage of S-Plus and SPSS to analyze this data. The S-Plus programming was used to impute missing data and SPSS was used to obtain the variations of ozone and also to clarify the relationship between stations. Results: Over the entire 10 year period (19972006), the trend in annual baseline ozone generally increased each year for all the four monitoring sites. There was also a seasonal variability in the measured ozone levels with high concentrations during the southwest monsoon and the northeast monsoon season, producing a significant increase in the amplitude of the seasonal cycle. The results also shown that the highest ozone concentrations were recorded at the Bukit Kuang air monitoring station (S1), with a daily mean value of $19 \mathrm{ppb}$ followed by the Indera Mahkota air monitoring station (S2). The concentration of ozone recorded at Kota Bharu (S3) and Kuala Terengganu (S4), two stations located in the city centre, was found to be lower than the values recorded at Bukit Kuang and Indera Mahkota. The correlation between $\mathrm{O}_{3}$ and $\mathrm{NO}$ is high at Kuala Terengganu (S4) $(\rho=-0.579)$, whilst the relationship between $\mathrm{O}_{3}$ and $\mathrm{NO}_{2}$ are high $(\rho=-0.397)$ at Indera Mahkota (S2). Conclusion: The concentration of ozone in the East Coast of Malaysian peninsula depends on the concentration of NOx and seasonal meteorological factors.
\end{abstract}

Key words: Concentration of ozone, Time series, Oxides of nitrogen, The Malaysian peninsula, Total Hydrocarbon (THC), Flame Ion Detector (FID), Package for Social Science (SPSS), ozone concentrations, photochemical production, solar radiation

\section{INTRODUCTION}

Photochemical oxidants are trace species, which are formed during the atmospheric photo-oxidation of a variety of trace gases (Kley et al., 1998; Rajab et al., 2010). Ozone, one of the most important photo-oxidants in the urban environment, originates from the in-situ photochemical production in the reactions of its precursors (NOx, CO, VOCs) and from vertical and horizontal transport (Minoura 1999; Latha and Badarinath, 2004; Badarinath et al., 2007; Lin et al., 2008; Ahmad et al., 2010). Due to the nature of ozone, its photolysis in the troposphere has been shown to be directly related to ultraviolet solar radiation at a wavelength of around $300 \mathrm{~nm}$, followed by a reaction of $\mathrm{OH}$ radicals, which take part in reactions responsible for the oxidation of other gases present in the atmosphere (Dentener and Crutzen 1993; Atkinson, 1997; Guicherit and Roemer 2000; Muzathik et al., 2010; Cansee et al., 2010; Charoensawan and Wannagosit, 2010).

The effects of ozone were introduced by Middleton et al. (1950) over 50 years ago (Lehman et al., 2004; Ali et al., 2009; 2010). On the scale of 100 years, the increasing trends of tropospheric ozone are qualitatively in agreement with emissions trends of precursors. This has led to the increase in the

Corresponding Author: Mohd Talib Latif, School of Environmental and Natural Resource Sciences, Faculty of Science and Technology, University Kebangsaan Malaysia, 43600 Bangi, Selangor Malaysia Tel: +603-89213822 Fax: +603-89253357 
tropospheric ozone level becoming one of the most crucial environmental problems needing to be solved in the coming decades due to its adverse effects, particularly on vegetation (Finlayson-Pits and Pitts 1997; Ishii et al., 2004; Ishii et al., 2007; Shan and Yin, 2008; Soleimanzadeh et al., 2010; Zouzoulas and Koutroubas, 2009). Hourly mean ozone recorded by the European Monitoring and Evaluation Programme (EMEP) rural ozone monitoring network, rarely approach zero and typically are $2-5 \mathrm{ppb}$ in relatively clean air masses which have had little influence from human activity (Hjellbrekke and Solberg, 2005; Azzi and Duc, 2008).

Recent investigations indicate that the concentration of ozone in the Earth's atmosphere is changing. Although there is a good agreement regarding a rise in background levels over the past century, in recent decades divergent trends in tropospheric ozone have been observed over different regions of the globe, especially in the north hemisphere (Vingarzan 2004; Zouzoulas and Koutroubas, 2009). Several researchers have demonstrated through data, the existence of a correlation between seasonal trends in the level of ozone concentrations are the local surroundings of various monitoring stations (Adeeb and Shooter 2004; Duenas et al., 2004; Feng et al., 2005; Lee et al., 2009; Piikki and Klingberg, 2009; Azmi et al., 2010). The trend analysis of ozone always has maintained a relationship with the trends of VOC, NO and NOx in both urban and suburban areas (Atkinson, 2000; Ghazali et al., 2010; Keuken et al., 2009; Martin et al., 2009; Milt et al., 2009). Local concentrations of ozone are reduced in the vicinity of heavy vehicular traffic as a results of ozone scavenging by $\mathrm{NO}$ and $\mathrm{NO}_{2}$ (Atkinson, 2000; Ahammed et al., 2006; Tu et al., 2007; Chen et al., 2009). On the other hand, areas with less traffic, specifically downwind of a monitoring station, may have a higher ozone concentration due to active photochemistry in an air mass enriched with precursor chemicals from motor vehicle exhaust gases (Lippmann, 1991; Afroz et al., 2005). In the case of Southeast Asia and other tropical countries, biomass burning especially from forest fire is also expected to contribute to the amount of ozone in the atmosphere. This is in addition to non-methane hydrocarbons from tropical forests (Komala and Saraspriya, 1996; Liu et al., 1999; Chan and Chan, 2000; Pochanart and Kreasuwun , 2001; Jusuf and Ibrahim, 2009).

The approach taken in this study is to focus on the surface ozone time series with relatively long records (10 years) and locations which are representative of the East Coast of Malaysia's geographical regions. This study also aims to quantify the overall monthly and daily trend for each of the monitoring sites other than the influence of atmospheric pollutants related to the ozone concentration recorded at each station. This study uses continuous observation for 10 years with data recorded every hour.

\section{METERIALS AND METHODS}

Sampling sites: The Eastern Coastal Region of the Malaysian peninsula (Fig. 1) has been chosen as the study site because it allows for the air quality in both urban and suburban areas to be determined, rather than solely the urban area as would have been the case had Kuala Lumpur been selected as the site of study. Furthermore, the East Coast of the Malaysian peninsula is a low pollutant area and was chosen specifically so that air quality could be determined in such a region. The meteorological condition in this region influence by the South West monsoon from June to September and North East monsoon November to March. The inter monsoon seasons usually occurred in month of April and October. The term East Coastal region is particularly used in Malaysia to refer to any one of the three states in the Malaysian peninsula facing the South China Sea. These states are Pahang, Kelantan and Terengganu, which have a total area of $64,911 \mathrm{~km}^{2}$, a total population of 4.5 million and a total density of 215 people $\mathrm{km}^{-2}$. The description of these monitoring stations is presented in Table 1.

The Bukit Kuang air monitoring station $\left(4.16^{\circ} \mathrm{N}\right.$, $103.25^{\circ} \mathrm{E}$; S1) located at a primary school and considered to be as far from urban areas but in close proximity to the main road connecting Kemaman and Kuala Terengganu. It is also around five kilometers from the Teluk Kalung Industrial areas. The Indera Mahkota air monitoring station $\left(3.49^{\circ} \mathrm{N}, 103.17^{\circ} \mathrm{E}\right.$; S2) located in Bandar Indera Mahkota Primary School is situated in a residential area about 4 kilometers northeast of Kuantan Town. This station is located in close proximity to the main road of the East Coast Expressway (LPT) via the Kuantan Interchange. Bandar Indera Mahkota is also more accessible to Sultan Haji Ahmad Shah Airport and Gambang through the Kuantan Bypass Highway. The Kota Bharu air monitoring station $\left(6.09^{\circ} \mathrm{N}, 102.15^{\circ} \mathrm{E}\right.$; S3) is located at Sultan Ismail College in Kota Bharu city center (capital state of Kelantan). There is quite a lot of traffic in this area, particularly during the morning and late afternoon rush hour. The Kuala Kuala Terengganu $\left(5.18^{\circ} \mathrm{N}\right.$, $103.07^{\circ} \mathrm{E}$; S4) air monitoring station is situated at the Chabang Tiga Primary School, which is located near to the Kuala Terengganu city center. 


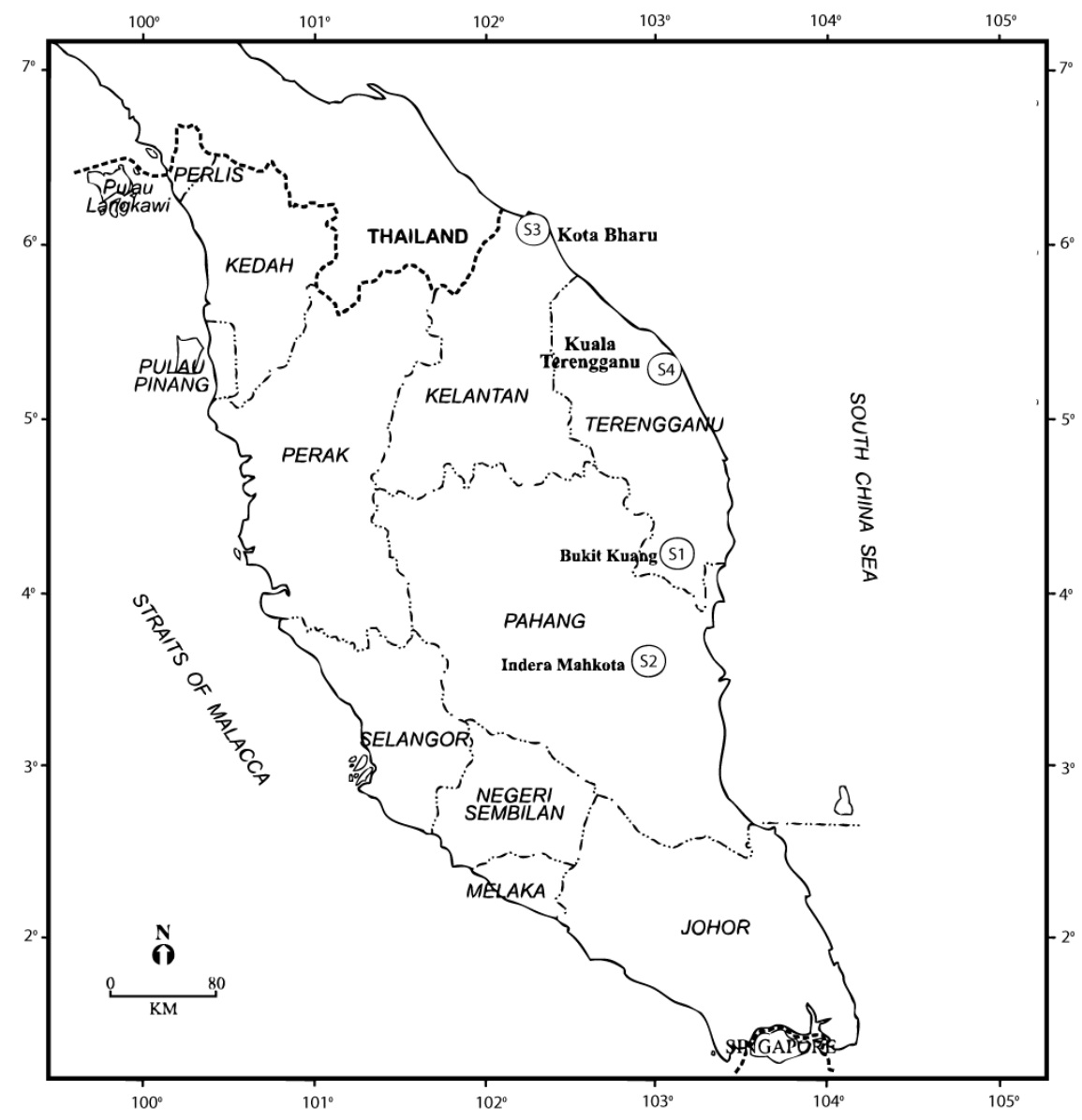

Fig. 1: Map of the Peninsula Malaysia with location of monitoring stations in the east coast of Malaysian peninsula

Table 1: Location and description of selected air monitoring stations on the eastern coast of the Malaysian peninsula

\begin{tabular}{|c|c|c|c|c|}
\hline Air monitoring station & Location & Background & Latitude & Longitude \\
\hline S1 & Bukit Kuang Primary School, Kemaman, Terengganu & Rural & $4.16^{\circ} \mathrm{N}$ & $103.25^{\circ} \mathrm{E}$ \\
\hline $\mathrm{S} 2$ & Indera Mahkota Primary School, Indera Mahkota, Pahang & Semi-Urban & $3.49^{\circ} \mathrm{N}$ & $103.17^{\circ} \mathrm{E}$ \\
\hline S3 & Sultan Ismail College, Kota Bharu, Kelantan & Urban & $6.09^{\circ} \mathrm{N}$ & $102.15^{\circ} \mathrm{E}$ \\
\hline S4 & Chabang Tiga Primary School, Kuala Terengganu, Terengganu & Urban & $5.18^{\circ} \mathrm{N}$ & $103.07^{\circ} \mathrm{E}$ \\
\hline
\end{tabular}

For this reason it also affected by busy traffic, particularly during the rush hour in the morning and late afternoon.

Ozone and other parameters data collections: The data for our investigation was obtained from the air quality monitoring sites in Malaysia, which though owned by the Department of the Environment (DOE) are managed a private company, Alam Sekitar Sdn. Bhd (ASMA). This data contains the monthly hourly average of ozone concentrations, oxides of nitrogen ( $\mathrm{NO}$ and $\mathrm{NO}_{2}$ ), Total Hydrocarbon (THC) and hourly meteorology measurements for variables such as: wind speed, air temperature, relative humidity and ultraviolet solar radiation.
The ozone concentration at Alam Sekitar Sdn. Bhd stations were measured using Teledyne Ozone Analyzer Model 400E UV Absorbtion. The analyzer uses a system based on the Beer-Lambert law for measuring low ranges of ozone in ambient air. The concentration of nitrogen oxides were determined using chemiluminescence measurement principle, coupled with state-of-the-art microprocessor technology for monitoring high and medium levels of nitrogen oxides (Teledyne Models 200EH and 200EM) while the concentration of total hydrocarbon THC was determined using field proven Flame Ion Detector (FID) (Teledyne Model 4020). In addition, meteorological parameters such as, wind speed, UV radiation and humidity also were also recorded at each station. 
Missing data: The "nearest neighbor method" has been used to impute missing data. This method for imputation is considered to be the simplest scheme available in the S-PLUS FinMetrics module, in that the endpoints of the gaps are used as estimates for all the missing values (Eq. (1)).

$\mathrm{y}=\mathrm{y}_{1}$ if $\mathrm{x} \leq \mathrm{x}_{1}+\left(\mathrm{x}_{2}-\mathrm{x}_{1}\right) / 2$,

$\mathrm{y}=\mathrm{y}_{2}$ if $\mathrm{x}>\mathrm{x}_{1}+\left(\mathrm{x}_{2}-\mathrm{x}_{1}\right) / 2$,

Where:

$\mathrm{Y}=$ The interpolant

$\mathrm{X}=$ Time point of the interpolant

$\mathrm{y}_{1}$ and $\mathrm{x}_{1}=$ The coordinates of the starting point of the gap

$y_{2}$ and $x_{2}=$ The coordinates of the end point of the gap

The data that was missing will be interpolated through the nearest neighbour value available using SPLUS (Junninen and Niska, 2004; Ali et al., 2008).

Statistical analysis: The data for ozone concentrations at each monitoring site was analyzed using the Statistical Package for Social Science (SPSS) 14.0 software, which was used to obtain the variations of ozone and also to clarify the relationship between stations. The statistics included in this software, which analyze the ozone concentration data, are descriptive statistics (frequency, graph and box plot) and bivariate statistics (correlation matrix). To see the relationship between different air pollutants at each station, the Spearman correlation was conducted in this study.

\section{RESULTS}

Variations in baseline ozone mixing ratios from 1997-2006: In general, average annual concentrations of ozone were recorded at the highest concentration in Bukit Kuang (S1) followed by Indera Mahkota (S2), Kota Bharu (S3) and Kuala Terengganu (S4). The annual mean of ozone concentrations recorded at Bukit Kuang (S1) increased steadily from $17 \mathrm{ppb}$ in 1997 to $20 \mathrm{ppb}$ in 2003, followed by a small decline and subsequent stabilization (Table 2 and Fig. 2). For Indera Mahkota (S2), the trends for ozone fluctuated between 1997 and 2003 and then became constant at the highest concentrations during 2004-2006 at $18 \mathrm{ppb}$ ozone concentrations. The opposite occurred with Kota Bharu (S3), where the constant annual mean of ozone was recorded at the low concentrations of $12 \mathrm{ppb}$ in 19982003 and then slightly increased to $14 \mathrm{ppb}$ in 20042006. The Kuala Terengganu (S4) annual mean concentrations have the highest value at $17 \mathrm{ppb}$ in 1999 and then decreased until 2003 before the value increased and returned to $17 \mathrm{ppb}$ in 2004.

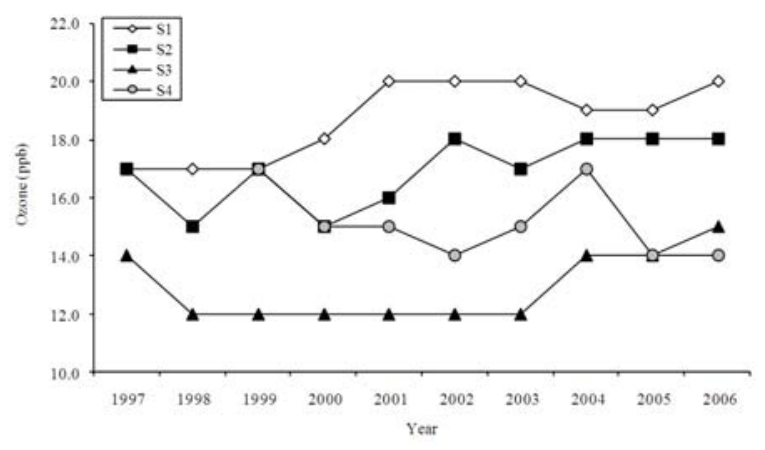

Fig. 2: Anual ozone concentrations recorded at selected monitoring stations

Monthly mean baseline levels of ozone at Bukit Kuang (S1) reached a peak of 27 ppb in July 2003, 25 ppb in August 2004 at Indera Mahkota (S2), 19 ppb in May 2005 at Kota Bharu (S3) and 23 ppb in December 2003 at Kuala Terengganu (S4). However, the month that shows the lowest range of ozone at Bukit Kuang (S1) was October 1999 with $11 \mathrm{ppb}$. This value has the same concentration as Indera Mahkota (S2) in November 2000 and 2003. The sites with the lowest concentrations of ozone among all of the four monitoring sites is Kota Bharu (S3) (Fig. 3), where the lowest concentration of $7 \mathrm{ppb}$ was recorded during October 2000 and 2001. The month which shows the lowest concentration of ozone at Kuala Terengganu (S4) is October with $9 \mathrm{ppb}$.

Monthly monitoring: Figure 3 shown the boxplot of monthly ozone concentration. The boxplot indicate that the concentration of ozone is higher during May to September (southwest Monsoon) and December to March (northeast Monsoon) and recorded at the lowest concentration during the inter-monsoon season (April and October).

Correlation between ozone and its precursors (NOx and THC) and meteorological factors: The concentration of ozone at all sampling stations has a negative correlation with the concentrations of $\mathrm{NO}, \mathrm{NO}_{2}$ and Total Hydrocarbon (THC) (Table 3). No THC concentration was observed at Kuala Terengganu (S4) as there was no instrument with which to measure THC concentration at this site. The results from Fig. 4 show that the monitoring stations with high concentrations of NO, such as Kota Bharu (S3) and Kuala Terengganu (S4), recorded low concentrations of ozone in comparison to Bukit Kuang (S1) and Indera Mahkota (S2). The strength of a linear relationship between ozone and NO is high at Kuala Terengganu (S4) based on the 
Am. J. Environ. Sci., 6 (6): 560-569, 2010

Table 2: Monthly mean of ozone concentration ( $\mathrm{ppb}$ ) at four sites on the east coast region of Malaysian peninsula

\begin{tabular}{|c|c|c|c|c|c|c|c|c|c|c|c|c|c|c|}
\hline & Year & Jan & Feb & Mar & Apr & May & Jun & Jul & Aug & Sep & Oct & Nov & Dec & Mean \\
\hline \multirow[t]{10}{*}{$\overline{\text { S1 }}$} & 1997 & 24 & 16 & 17 & 16 & 19 & 22 & 22 & 26 & 26 & 20 & 16 & 17 & 20 \\
\hline & 1998 & 16 & 14 & 19 & 20 & 16 & 17 & 18 & 15 & 20 & 17 & 14 & 15 & 17 \\
\hline & 1999 & 17 & 20 & 12 & 14 & 18 & 14 & 22 & 22 & 21 & 11 & 13 & 22 & 17 \\
\hline & 2000 & 19 & 20 & 13 & 15 & 21 & 16 & 17 & 22 & 20 & 18 & 14 & 17 & 18 \\
\hline & 2001 & 17 & 19 & 18 & 17 & 21 & 21 & 26 & 23 & 23 & 17 & 19 & 21 & 20 \\
\hline & 2002 & 22 & 19 & 16 & 15 & 20 & 24 & 25 & 25 & 23 & 19 & 15 & 15 & 20 \\
\hline & 2003 & 22 & 16 & 15 & 13 & 20 & 21 & 27 & 23 & 24 & 19 & 14 & 26 & 20 \\
\hline & 2004 & 20 & 19 & 17 & 15 & 21 & 21 & 18 & 26 & 19 & 18 & 14 & 19 & 19 \\
\hline & 2005 & 24 & 14 & 18 & 15 & 21 & 21 & 21 & 24 & 21 & 15 & 15 & 17 & 19 \\
\hline & 2006 & 21 & 16 & 15 & 15 & 17 & 21 & 23 & 25 & 24 & 20 & 16 & 23 & 20 \\
\hline \multirow[t]{10}{*}{ S2 } & 1997 & 19 & 14 & 15 & 15 & 18 & 19 & 18 & 21 & 23 & 16 & 12 & 12 & 17 \\
\hline & 1998 & 14 & 12 & 14 & 16 & 16 & 17 & 19 & 15 & 18 & 16 & 15 & 14 & 15 \\
\hline & 1999 & 14 & 16 & 13 & 16 & 17 & 20 & 22 & 22 & 24 & 13 & 12 & 16 & 17 \\
\hline & 2000 & 13 & 17 & 13 & 15 & 18 & 16 & 19 & 18 & 17 & 14 & 11 & 14 & 15 \\
\hline & 2001 & 12 & 16 & 14 & 14 & 15 & 16 & 20 & 16 & 17 & 16 & 15 & 19 & 16 \\
\hline & 2002 & 19 & 18 & 18 & 16 & 18 & 20 & 18 & 21 & 20 & 22 & 14 & 13 & 18 \\
\hline & 2003 & 19 & 15 & 16 & 14 & 19 & 20 & 16 & 21 & 19 & 15 & 11 & 19 & 17 \\
\hline & 2004 & 16 & 18 & 16 & 17 & 20 & 20 & 17 & 25 & 18 & 19 & 15 & 18 & 18 \\
\hline & 2005 & 23 & 18 & 19 & 17 & 19 & 19 & 19 & 22 & 20 & 14 & 14 & 16 & 18 \\
\hline & 2006 & 20 & 14 & 17 & 15 & 16 & 18 & 19 & 22 & 22 & 19 & 13 & 18 & 18 \\
\hline \multirow[t]{10}{*}{ S3 } & 1997 & 12 & 12 & 15 & 14 & 15 & 19 & 17 & 15 & 16 & 12 & 11 & 13 & 14 \\
\hline & 1998 & 12 & 10 & 16 & 17 & 15 & 14 & 12 & 11 & 9 & 8 & 9 & 12 & 12 \\
\hline & 1999 & 14 & 13 & 11 & 10 & 13 & 14 & 13 & 12 & 11 & 9 & 9 & 17 & 12 \\
\hline & 2000 & 14 & 15 & 10 & 12 & 12 & 11 & 13 & 10 & 12 & 7 & 11 & 11 & 12 \\
\hline & 2001 & 12 & 14 & 11 & 11 & 14 & 12 & 16 & 9 & 11 & 7 & 12 & 13 & 12 \\
\hline & 2002 & 15 & 13 & 12 & 11 & 14 & 15 & 13 & 13 & 9 & 9 & 8 & 9 & 12 \\
\hline & 2003 & 15 & 10 & 10 & 9 & 11 & 18 & 11 & 13 & 11 & 8 & 10 & 18 & 12 \\
\hline & 2004 & 16 & 16 & 17 & 16 & 17 & 15 & 13 & 16 & 14 & 10 & 8 & 8 & 14 \\
\hline & 2005 & 13 & 9 & 11 & 16 & 19 & 17 & 16 & 16 & 14 & 12 & 13 & 15 & 14 \\
\hline & 2006 & 16 & 13 & 15 & 14 & 15 & 15 & 18 & 16 & 15 & 14 & 12 & 18 & 15 \\
\hline \multirow[t]{8}{*}{ S4 } & 1999 & 20 & 21 & 12 & 15 & 16 & 19 & 18 & 18 & 16 & 9 & 13 & 22 & 17 \\
\hline & 2000 & 19 & 19 & 14 & 14 & 16 & 13 & 17 & 15 & 16 & 10 & 13 & 15 & 15 \\
\hline & 2001 & 16 & 16 & 13 & 13 & 15 & 14 & 19 & 16 & 15 & 11 & 15 & 19 & 15 \\
\hline & 2002 & 20 & 14 & 13 & 10 & 15 & 16 & 15 & 16 & 15 & 14 & 11 & 13 & 14 \\
\hline & 2003 & 21 & 14 & 11 & 11 & 12 & 17 & 13 & 17 & 14 & 11 & 11 & 23 & 15 \\
\hline & 2004 & 18 & 17 & 19 & 16 & 17 & 16 & 16 & 21 & 16 & 17 & 14 & 21 & 17 \\
\hline & 2005 & 20 & 9 & 14 & 11 & 14 & 13 & 16 & 15 & 16 & 11 & 12 & 14 & 14 \\
\hline & 2006 & 16 & 14 & 12 & 10 & 12 & 14 & 16 & 18 & 15 & 14 & 10 & 18 & 14 \\
\hline
\end{tabular}

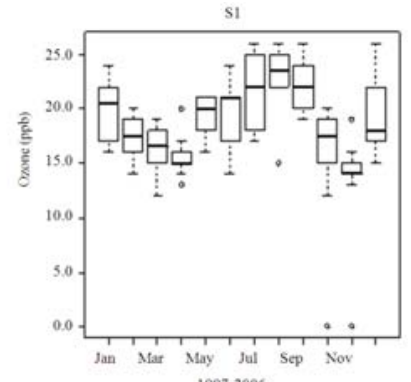

(a)

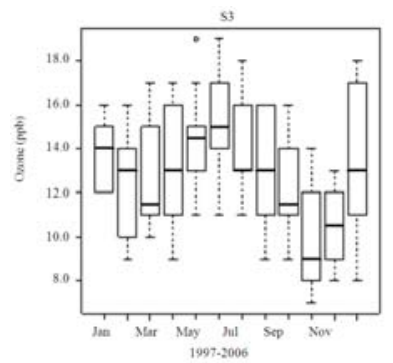

(c)

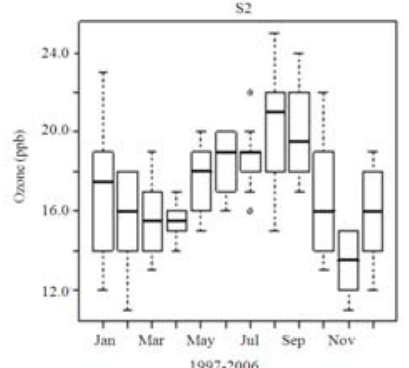

(b)

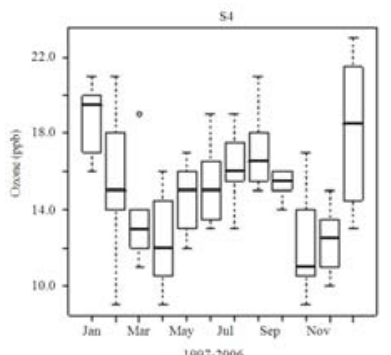

(d)

Fig. 3: Box plot of ozone concentrations over an annual cycle during 1997-2006 at selected monitoring stations 
Am. J. Environ. Sci., 6 (6): 560-569, 2010

Table 3: Correlation ( $\rho$-value) between parameters at monitoring stations

\begin{tabular}{|c|c|c|c|c|c|}
\hline Stations & Parameters & $\mathrm{O}_{3}$ & $\mathrm{NO}$ & $\mathrm{NO}_{2}$ & $\mathrm{THC}$ \\
\hline \multirow[t]{4}{*}{$\overline{\text { Bukit Kuang (S1) }}$} & $\mathrm{O}_{3}$ & 1 & & & \\
\hline & NO & $-0.537^{* *}$ & 1 & & \\
\hline & $\mathrm{NO}_{2}$ & $0.271^{* *}$ & -0.107 & 1 & \\
\hline & THC & $-0.441^{* *}$ & $0.342^{* *}$ & $-0.359^{* *}$ & 1 \\
\hline \multirow[t]{4}{*}{ Indera Mahkota (S2) } & $\mathrm{O}_{3}$ & 1 & & & \\
\hline & NO & $-0.310 * *$ & 1 & & \\
\hline & $\mathrm{NO}_{2}$ & $-0.397 * *$ & $0.558 * *$ & 1 & \\
\hline & THC & $-0.717 * *$ & $0.382 * *$ & $0.411 * *$ & 1 \\
\hline \multirow[t]{4}{*}{ Kota Bharu (S3) } & $\mathrm{O}_{3}$ & 1 & & & \\
\hline & NO & $-0.281 * *$ & 1 & & \\
\hline & $\mathrm{NO}_{2}$ & $-0.160 *$ & $0.589 * *$ & 1 & \\
\hline & THC & $-0.866 * *$ & 0.109 & 0.066 & 1 \\
\hline \multirow[t]{3}{*}{ Kuala Terengganu (S4) } & $\mathrm{O}_{3}$ & 1 & & & \\
\hline & $\mathrm{NO}$ & $-0.579 * *$ & 1 & & \\
\hline & $\mathrm{NO}_{2}$ & $-0.272 * *$ & $0.647 * *$ & 1 & \\
\hline
\end{tabular}

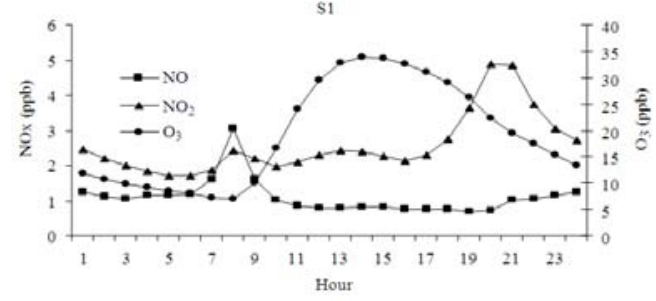

(a)

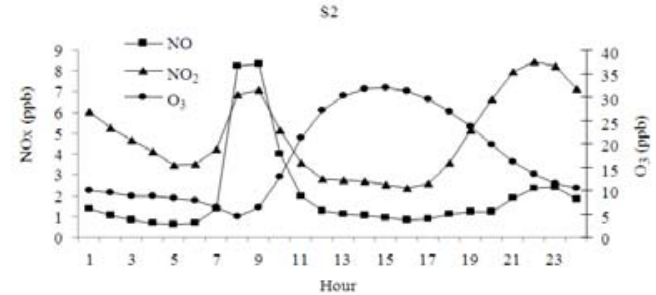

(b)

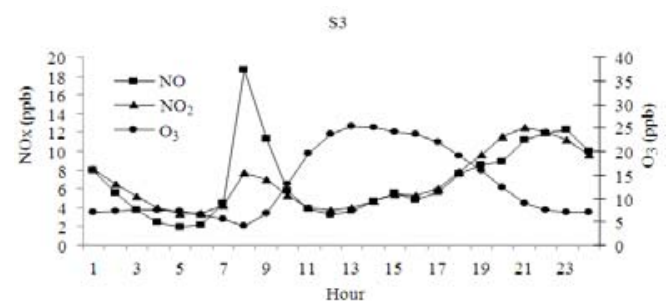

(c)

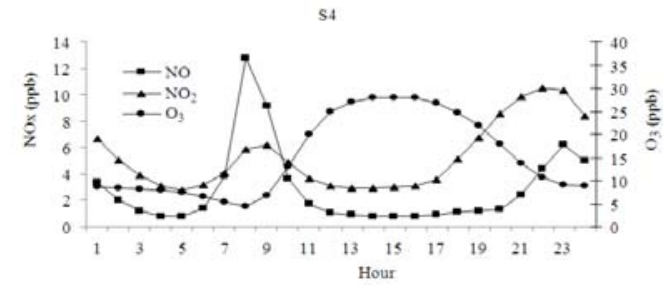

Fig. 4: Diurnal concentration of $\mathrm{O}_{3}$ compared to $\mathrm{NO}$ and $\mathrm{NO}_{2}$ at selected monitoring stations

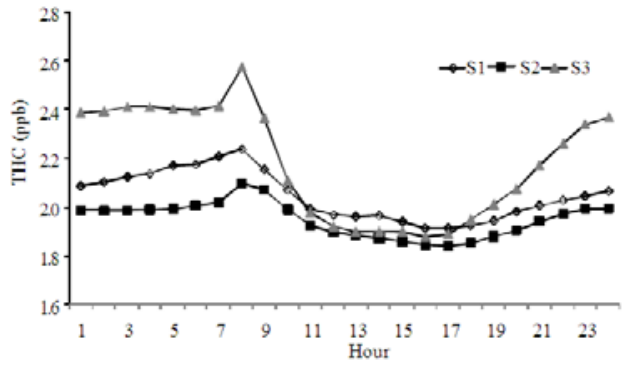

Fig. 5:Diurnal of total hydrocarbon (THC) concentrations recorded at selected monitoring stations (S1, S2 and S3)

value of $\rho=-0.579$ (negatively correlated) at a significant level of 0.01 . Nevertheless, for most of the stations the negative hourly correlation between $\mathrm{NO}_{2}$ and ozone were not as strong as the correlation between NO and ozone with the exception of Indera Mahkota where the rho value is $\rho=-0.310$.

The relationship between $\mathrm{NO}$ and $\mathrm{NO}_{2}$ are positively correlated at the highest value of rho, $\rho=0.647$ at Kuala Terengganu (S4) and negatively correlated at the smallest value of rho, $\rho=-0.107$ at Bukit Kuang (S1).

The ozone concentrations at all stations show a strong negative correlation with Total Hydrocarbon (THC) in the atmosphere. The strongest correlation of ozone and THC was found at Kota Bharu $(\rho=-0.866)$.

Correlation between ozone and meteorological factors (Fig. 6) indicates that the ozone concentration has a significant positive correlation with $\mathrm{UV}$ radiation $(\mathrm{r}=$ $0.02, \mathrm{p}<0.01)$. Besides, there is a negative correlation between humidity and ozone in ambient air with $\mathrm{r}=$ $0.06, \mathrm{p}<0.01$. The results showed that the cross correlation between ozone and wind speed have a negative correlation with $\mathrm{r}=-0.109, \mathrm{p}<0.01$. 


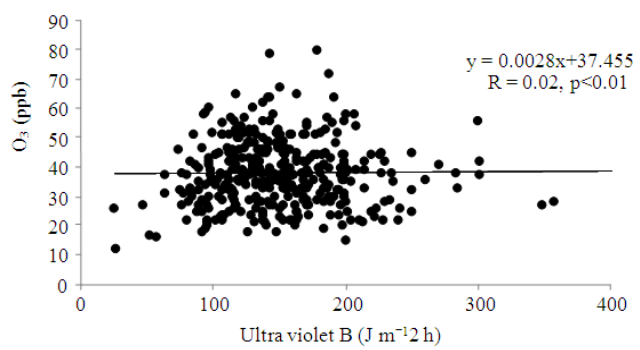

(a)

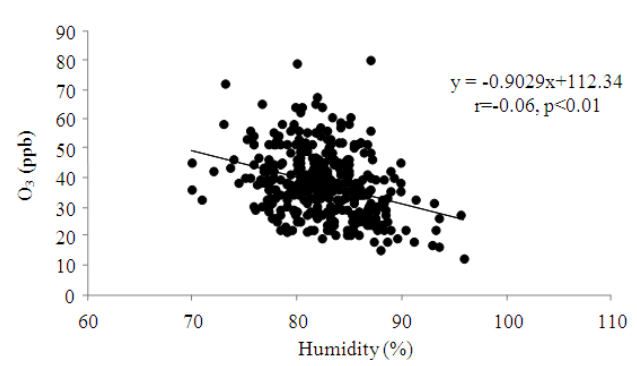

(b)

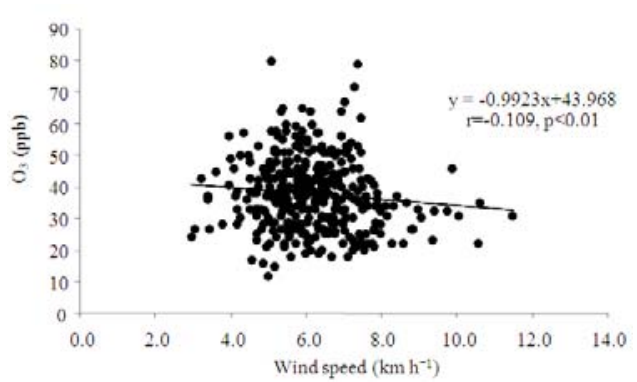

(c)

Fig. 6: Correlation between $\mathrm{O}_{3}$ and meteorolical factors

\section{DISCUSSION}

The concentration of ozone recorded at Kota Bharu (S3) and Kuala Terengganu (S4), two stations located in the city centre where there was more traffic, were found to be lower than the values recorded at both Bukit Kuang (S1) and Indera Mahkota (S2). These results concur with research undertaken by Keuken et al. (2009), which found that the highest values of ozone are obtained in suburban areas where the influence of road traffic is lower.

The boxplot in the Fig. 3 could indicate the maximum, minimum, mean, 1 st and also 3 rd quartile values of the concentration. The data that not included between the whiskers is known as outliers with a dot sign.

Strong winds during the monsoon season are capable of transporting ozone the long distances to the monitoring stations as is suggested by Akimoto (1996),
Pochanart and Kreasuwun (2001), Lu and Wang (2006), Ishii et al. (2007), Al-Jeran and Khan (2009) and Shan et al. (2009). These particular seasons (May to September) and (December to March) can also be correlated to biomass burning in Southeast Asia, particularly from Sumatra, Indonesia and Indochina respectively.

High concentrations of $\mathrm{NO}$, are capable of reacting with $\mathrm{NO}$ and producing other $\mathrm{NO}_{\mathrm{x}}$, such as $\mathrm{NO}_{2}$. The amount of ozone found to be reduced by the concentration of NO expected, is contributed to by the exhaust of motor vehicles from the nearby roads as is stated in several other studies (Finlayson-Pits and Pitts 1997; Atkinson, 2000; Al-Azmi et al., 2008). Motor vehicles, particularly those moving at low speeds in the city, will emit a high amount of NO into the atmosphere (Ahammed et al., 2006). $\mathrm{NO}$ than will oxidise to $\mathrm{NO}_{2}$ in the atmosphere as a result of the reaction with ozone.

The correlation between $\mathrm{NO}_{2}$ and $\mathrm{O}_{3}$ recorded at Bukit Kuang was a positive correlation, which indicates that the $\mathrm{NO}_{2}$ at this station has the ability to produce $\mathrm{O}_{3}$ in the atmosphere. The concentration of THC recorded at Bukit Kuang (S1), Indera Mahkota (S2) and Kota Bharu (S3) found to have same trends as the concentration of NO (Fig. 5) expected contribute by the number of motor vehicles.

The reaction of $\mathrm{NO}$ and $\mathrm{O}_{3}$ in the atmosphere, as mentioned, will produce $\mathrm{NO}_{2}$ and this is indicated by the correlation between $\mathrm{NO}$ and $\mathrm{NO}_{2}$. The relationship between $\mathrm{NO}$ and $\mathrm{NO}_{2}$ are positively correlated at Kuala Terengganu (S4) and negatively correlated at Bukit Kuang (S1) demonstrates that the amount of NO to react with $\mathrm{O}_{3}$ at the rural site of Bukit Kuang is very limited and let to the high concentration of $\mathrm{O}_{3}$ recorded at this station. This is shown by other studies of $\mathrm{O}_{3}$ concentrations at rural sites, as reported by Kelly et al. (1984) and Al-Azmi et al. (2008).

The ozone concentrations at all stations show a strong negative correlation with Total Hydrocarbon (THC) in the atmosphere. The strongest correlation of ozone and THC was found at Kota Bharu. These results concur with those from a number of other studies focused on the correlation between ozone and total hydrocarbon and black carbon in urban areas, e.g., by Latha and Badarinath (2004) and Al-Jeran and Khan (2009).

In order to study ozone variability in East Coast Region of Malaysian peninsula, it is therefore necessary to know the relationships between ozone and the meteorological parameters. The wind is a meteorological variable that strongly affects the ozone concentration, since it determines the transport and dispersion of both ozone and its precursors. Therefore, the correlation between ozone and wind speed is also been studied here. 


\section{CONCLUSION}

Over the 10-year period (1997-2006), annual mean ozone ranges rose between 12-20 ppb year ${ }^{-1}$ in the East Coast of the Malaysian peninsula. With regard to the trends of ozone at each site, the highest ozone concentrations in the East Coast of the Malaysian peninsula were recorded at Bukit Kuang (S1) with a 10year mean value of $19 \mathrm{ppb}$, while the smallest ozone concentrations were at Kota Bharu city centre (S3) with a 10 -year mean value of $13 \mathrm{ppb}$. During this 10 -year study period, baseline ozone levels reached a peak of 27 ppb in July 2003, as was documented at Bukit Kuang (S1). In terms of the concentration of primary air pollutants, NO was expected to influence the amount of ozone, specifically at the stations located near too busy roads, $\mathrm{NO}$ then oxidised to $\mathrm{NO}_{2}$ in the ambient air. Our study showed that overall, most of the $\mathrm{O}_{3}$ recorded at sampling stations had a negative correlation with $\mathrm{NO}$, $\mathrm{NO}_{2}$ and THC. The research indicates that the ozone level is also affected (positively or negatively) by meteorological conditions, e.g., solar radiation, humidity and wind speed. The results obtained in this study can be used as a physical basis to predict ozone concentration levels in this area.

This study also shows a very strong seasonal variation in ozone concentrations, with higher concentrations observed during the southwest and northeast monsoon. The concentration of ozone was expected to be influenced by the amount of various chemical species in the atmosphere, e.g., $\mathrm{CO}, \mathrm{NO}, \mathrm{NO}_{\mathrm{x}}$ and $\mathrm{OH}$, as a result of oxidation and photochemical processes. The complex reactions due to biomass burning contribute to the long range of ozone distribution and are expected to influence the amount of ozone in the Southeast Asian region.

\section{ACKNOWLEDGMENT}

The researchers would like to thank University Kebangsaan Malaysia for Research University Grant (UKM-GUP-ASPL-07-05-140, UKM-GUP-ASPL-0705-138 and UKM-ST-06-FRGS0009-2008) and the Malaysian Department of the Environment (DOE) for air quality data.

\section{REFERENCES}

Adeeb, F. and D. Shooter, 2004. Variation of surface ozone in the ambient air of Auckland, New Zealand. Environ. Monit. Assess., 95: 201-220. DOI: 10.1023/B:EMAS.0000029904.28706.c0
Afroz, R., M.N. Hassan, M. Awang and N.A. Ibrahim, 2005. Willingness to Pay for Air Quality Improvements in Klang Valley Malaysia. Am. J. Environ. Sci., 1: 194-201. DOI: 10.3844/ajessp.2005.194.201

Ahammed, Y.N., R.R. Reddy, K.R. Gopal, K. Narasimhulu, D.B. Basha, L.S.S. Reddy and T.V.R. Rao, 2006. Seasonal variation of the surface ozone and its precursor gases during 2001-2003, measured at Anantapur $\left(14.62^{\circ} \mathrm{N}\right)$, a semi-arid site in India. Atmos. Res., 80: 151-164. DOI: 10.1016/j.atmosres.2005.07.002

Ahmad, M.M., M.F.R. Nordin and M.T. Azizan, 2010. Upgrading of Bio-Oil into High-Value Hydrocarbons via Hydrodeoxygenation. Am. J. Applied Sci., 7: 746-755. DOI: 10.3844/ajassp.2010.746.755

Akimoto, H., 1996. Long-range transport of ozone in the East Asian Pacific rim region. J. Geophys. Res., 101: 1999-2010.

Al-Azmi, B.N., V. Nassehi and A.R. Khan, 2008. Impact of emissions from power stations on the ambient air quality of selected urban areas in Kuwait. Am. J. Environ. Sci., 4: 558-568. DOI: 10.3844/ajessp.2008.50.62

Ali, A., A. Alfarhan, I. Aldjain and N. Bokhari, 2009. Effect of ambient gasess on respiration of soil supporting four crops in central Saudi Arabia. Am. J. Applied Sc., 6: 456-462. DOI: 10.3844/ajas.2009.456.462

Ali, A., A. Alfarhan, E. Robinson, N. Bokhari, K. Al Rashied and S. Al Quraishy 2008. Tropospheric ozone effects on the productivity of some crops in central Saudi Arabia. Am. J. Environ. Sci., 4: 631-637. DOI: 10.3844/ajessp.2008.631.637

Al-Jeran, H.O. and A.R. Khan, 2009. The Effect of Air Pollution on Ozone Layer Thickness in Troposphere over the State of Kuwait. Am. J. Environ. Sci., 5: 230-237. DOI: 10.3844/ajessp.2009.230.237

Atkinson, R., 1997. Gas-phase tropospheric chemistry of volatile organic compounds: 1. Alkanes and alkenes. J. Physical Chem., 26: 215-290.

Atkinson, R., 2000. Atmospheric chemistry of VOCs and $\mathrm{NO}(\mathrm{x})$. Atmos. Environ., 34: 2063-2101. DOI: 10.1016/S1352-2310(99)00460-4

Azmi, S. Z., M.T. Latif, A.S. Ismail, L. Juneng and A.A. Jemain, 2010. Trend and status of air quality at three different monitoring stations in the Klang Valley, Malaysia. Air Qual. Atmos Health, 3: 53-64. DOI: $10.1007 / \mathrm{s} 11869-009-0051-1$ 
Azzi, M. and H. Duc, 2008. Recent Trends in Ozone and Particle Concentrations in the Sydney (Australia) Airshed. Am. J. Environ. Sci., 4: 454-461. DOI: 10.3844/ajessp.2008.454.461

Badarinath, K.V.S., K.M. Latha T.R.K. Chand, R.R. Reddy, K.R. Gopal, L.S.S. Reddy, K. Narasimhulu and K.R. Kumar, 2007. Black carbon aerosols and gaseous pollutants in an urban area in North India during a fog period. Atmos. Res., 85: 209-216. DOI: 10.1016/j.atmosres.2006.12.007

Cansee, S., A. Pattiya, S. Pattanasethanon and W. Sombuttera, 2010. A study of solar reflector efficiency of parabolic dual trough. Energy Res. J., 1: 116-119. DOI: 10.3844/erjsp.2010.116.119

Chan, L.Y. and C.Y. Chan, 2000. A case study on the biomass burning in southeast asia and enhancement of tropospheric ozone over Hong Kong. Geophys. Res. Lett., 27: 1479-1482.

Charoensawan, P. and C. Wannagosit, 2010. Computational study of hybrid water heater with evacuated glass tube solar collector and rice husk combustion. Energy Res. J., 1: 182-188. DOI: 10.3844/erjsp.2010.182.188

Chen, J., W. Wang, J. Zhang, H. Liu, L. Ren, X. Liu, W. Zhang and X. Wang., 2009. Characteristics of gaseous pollutants near a main traffic line in Beijing and its influencing factors. Atmos. Res., 94: 470-480. DOI: 10.1016/j.atmosres.2009.07.008

Dentener, F.J. and P.J. Crutzen, 1993. Reaction of $\mathrm{N} 2 \mathrm{O} 5$ on tropospheric aerosols: impact on the global distributions of $\mathrm{NOx}, \mathrm{O} 3$ and $\mathrm{OH}$. J. Geophys. Res., 98: 7149-7163.

Duenas, C., M.C. Fernandez, S. Canete, J. Carretero and E. Liger, 2004. Analyses of ozone in urban and rural sites in Malaga (Spain). Chemosphere, 56: 631-639.

DOI: 10.1016/j.chemosphere.2004.04.013

Feng, Y.W., N. Ohta and H. Shimizu, 2005. Decline of Betula ermanii with special reference to ozone concentration at Mt. Mae-Shirane, Oku-Nikko, Japan. Am. J. Applied Sci., 2: 701-706. DOI: 10.3844/ajassp.2005.701.706

Finlayson-Pits, B.J. and J.J.N. Pitts, 1997. Tropospheric air pollution: ozone, airborne toxics, polycyclic aromatic hydrocarbons and particles. Sci., 276: 1045-1051.

Ghazali, N. A., N.A. Ramli, A.S. Yahaya, N.F.F.M. Yusof and N. Sansuddin et al., 2010. Transformation of nitrogen dioxide into ozone and prediction of ozone concentrations using multiple linear regression techniques. Environ. Monit. Assess., 165: 475-489. DOI: 10.1007/s10661-009-0960-3
Guicherit, R. and M. Roemer, 2000. Tropospheric ozone trends. Chemosphere-Global Change Sci., 2: 167-183.

Hjellbrekke, A.G. and S. Solberg, 2005. Ozone measurements 2003. EMEP/CCC-Report 4/2005. Kjeller. Norwegian Institute for Air Research, Norway.

Ishii, S. and F.M. Marshall and J.N.B. Bell, 2004. Impact of ambient air pollution on locally grown rice cultivars (Oryza sativa L.) in Malaysia. Water Air Soil Pollut., 154: 187-201. DOI: 10.1023/B:WATE.0000026528.86641.5b

Ishii, S., J.N.B. Bell and F.M. Marshall, 2007. Phytotoxic risk assessment of ambient air pollution on agricultural crops in Selangor State, Malaysia. Environ. Pollut., 150: 267-279. DOI: 10.1016/j.envpol.2007.01.012

Junninen, H. and H. Niska, 2004. Methods for imputation of missing values in air quality data sets. Atmos. Environ., 38: 2895-2907. DOI: 10.1016/j.atmosenv.2004.02.026

Kelly, N. A. and G.T. Wolff, 1984. Sources and sinks of ozone in rural areas. Atmos. Environ. General Topics, 18: 1251-1266.

Keuken, M., M. Roemer and S. Elshout, 2009. Trend analysis of urban $\mathrm{NO} 2$ concentrations and the importance of direct NO2 emissions versus ozone/NOx equilibrium. Atmos. Environ., 43: 4780-4783. DOI: 10.1016/j.atmosenv.2008.07.043

Kley, D., M. Kleinmann and S. Krupa, 1998. Photochemical oxodants: State of the science. Environ. Pollutant, 100: 19-42. DOI: 10.1016/S0269-7491(99)00086-X

Komala, N. and S. Saraspriya, 1996. Tropospheric ozone behavior observed in Indonesia. Atmos. Environ., 30: 1851-1856. DOI: 10.1016/13522310(95)00382-7

Latha, K.M. and K.V.S. Badarinath, 2004. Correlation between black carbon aerosols, carbon monoxide and tropospheric ozone over a tropical urban site. Atmos. Res., 71: 265-274. DOI: 10.1016/j.atmosres.2004.06.004

Lee, Y.C., M. Wenig and X. Yang, 2009. The emergence of urban ozone episodes in autumn and air temperature rise in Hong Kong. Air Qual. Atmos. Health, 2: 111-121. DOI: 10.1007/s11869009-0038-y

Lehman, J., K. Swinton, S. Botnick, C. Hamilton, E. Baldridge, B. Ede and B. Cox, 2004. Spatiotemporal characterization of tropospheric ozone across the eastern United States. Atmos. Environ., 38: 4357-4369. DOI: 10.1016/j.atmosenv.2004.03.069 
Lin, W., X. Xu, X. Zhang and J. Thang, 2008. Contributions of pollutants from North China plain to surface of ozone at the Shangdianzi GAW Station. Atmos. Chem. Phys., 8: 5889-5898.

Lippmann, M., 1991. Health effects of tropospheric ozone. Environ. Sci. Technology, 25: 1954-1962.

Liu, H., W.L. Chang, S.J. Oltmans, L.Y. Chan and J.M. Harris, 1999. On springtime high ozone events in the lower troposphere from Southeast Asian biomass burning. Atmos. Environ., 33: 2403-2410. DOI: 10.1016/S1352-2310(98)00357-4

Lu, W.Z. and X.K. Wang, 2006. Evolving trend and self-similarity of ozone pollution in central Hong Kong ambient during 1984-2002. Sci. Total Environ., 357: 160-168. DOI: 10.1016/j.scitotenv.2005.03.015

Martin, P., B. Cabañas, F. Villanueva, M.P. Gallego, I. Colmenar and S. Salgado, 2009. Ozone and nitrogen dioxide levels monitored in an urban area (Ciudad Real) in central-southern Spain. Water Air Soil Pollut, 10: 11270-009-0168-8. DOI: 10.1007/s1 1270-009-0168-8

Middleton, J.T., J.B. Kendrick and H.W. Schwalm, 1950. Injury to herbaceous plants by smog or air pollution. Plant Disease Reporter, 34: 245-252.

Milt, A., A. Milano, S. Garivait and R. Kamens, 2009. Effects of $10 \%$ biofuel substitution on ground level ozone formation in Bangkok, Thailand. Atmos. Environ., 1-9. DOI: 10.1016/j.atmosenv.2009.07.062

Minoura, H., 1999. Some characteristics of surface ozone concentration observed in an urban atmosphere. Atmos. Res., 51: 153-169. DOI: 10.1016/S0169-8095(99)00003-4

Muzathik, A.M., W.M.N. Wan, K.S. Nik and M.Z. Ibrahim, 2010. Reference solar radiation year and some climatology aspects of east coast of West Malaysia. Am. J. Engineer. Applied Sci., 3: 293-299.
Piikki, K. and J. Klingberg, 2009. Estimates of AOT ozone indices from time-integrated ozone data and hourly air temperature measurements in southwest Sweden. Environ. Pollut., 157: 3051-3058. DOI: 10.1016/j.envpol.2009.05.038

Pochanart, P. and J. Kreasuwun, 2001. Tropical tropospheric ozone observed in Thailand. Atmos. Environ., 35: 2657-2668. DOI: 10.1016/S13522310(00)00441-6

Rajab, J.M., M.Z. MatJafri, H.S. Lim and K. Abdullah, 2010. Daily distribution map of ozone $\left(\mathrm{O}_{3}\right)$ from AIRS over Southeast Asia. Energy Res. J., 1: 158-164. DOI: $10.3844 /$ erjsp.2010.158.164

Shan, W. and Y. Yin, 2008. Observational study of surface ozone at an urban site in East China. Atmos. Res., 89: 252-261. DOI: 10.1016/j.atmosres.2008.02.014

Shan, W., Y. Yin, H. Lu and S. Liang, 2009. A meteorological analysis of ozone episodes using HYSPLIT model and surface data. Atmos. Res., 93: 767-776. DOI: 10.1016/j.atmosres.2009.03.007

Soleimanzadeh, H., D. Habibi, M.R. Ardakani, F. Paknejad and F. Rejali, 2010. Effect of Potassium Levels on Antioxidant Enzymes and Malondialdehyde Content under Drought Stress in Sunflower (Helianthus annuus L.). Am. J. Agric. Biol. Sci., 5: 56-61. DOI: 10.3844/ajabssp.2010.56.61.

Tu, J., Z.G. Xia and W.Q. Li, 2007. Temporal variations in surface ozone and its precursors and meteorological effects at an urban site in China. Atmos. Res., 85: 310-337. DOI: 10.1016/j.atmosres.2007.02.003

Vingarzan, R., 2004. A review of surface ozone background levels and trends. Atmos. Environ., 38: 3431-3442. DOI: 10.1016/j.atmosenv.2004.03.030

Zouzoulas, D. and S.D. Koutroubas, 2009. Effects of ozone fumigation on cotton (Gossypium hirsutum L.) morphology, anatomy, physiology, yield and qualitative characteristics of fibers. Environ. Experimental Botany, 67: 293-303. 